\title{
DESTINATION BRANDING OF TERAS CIKAPUNDUNG: A MODEL OF COMMUNICATION STRATEGY
}

\author{
Agustin Rozalena $^{1 *}$, lis Saidah ${ }^{2}$ \\ ${ }^{1}$ Administrasi Keuangan, ${ }^{2}$ Manajemen Informatika Polieknik Piksi Ganesha \\ Jl. Gatot Soebroto No. 301 Bandung, Indonesia \\ Email: ${ }^{1}$ alen.rozalena@gmail.com; ${ }^{2}$ iissaidah88@gmail.com \\ *Penulis korespondensi
}

\begin{abstract}
This aims to construct model of brand communication strategy with the research subjects being the informants related to the construction of the Teras Cikapundung around the riverbanks and borders of the Cikapundung River. The research is qualitative with a construction paradigm and case study analysis. Researchers use depth interviewing techniques, Focus Group Discussion, observation, analysis of documents and data analysis technique used an interactive model. The results of the study are 1) the process of forming the communication of the city tourism brand made by Teras Cikapundung through the elaboration of the MESSAGE Model and destination branding strategy; 2) the existence of the Teras Cikapundung based on three elements of reinforcement through field trips, community awareness and environmental cleanliness, Kliatchko's Model of Integrated Marketing Communication (IMC) and strategic management of the Teras Cikapundung's Brand Communication Programs; 3) communication strategy model of the city tour brand made by Teras Cikapundung which shows the sequence of construction activities carried out by the communicator.
\end{abstract}

Keywords: Brand communication strategy; Teras Cikapundung; man made tourism.

\begin{abstract}
ABSTRAK
Penelitian ini bertujuan untuk mengontruksi model strategi komunikasi merek merupakan penelitian dengan objek komunikasi merek kota dengan subjek penelitian para informan yang berkaitan dengan terbangunnya Teras Cikapundung di sekitar bantaran dan sempadan Sungai Cikapundung. Penelitian ini bersifat kualitatif dengan paradigma kontruksi serta analisis studi kasus. Peneliti menggunakan teknik depth interviewing, Focus Group Discussion (FGD), observasi, analisis dokumen serta teknik analisis data menggunakan model interaktif. Hasil penelitian menyatakan 1) proses pembentukan komunikasi merek wisata kota buatan Teras Cikapundung melalui elaborasi Model MESSAGE dan destination branding strategy; 2) adanya strategi wisata buatan Teras Cikapundung berdasarkan tiga unsur penguatan melalui lokasi karyawisata, kesadaran komunitas dan kebersihan lingkungan, Kliatchko's Model of Integrated Marketing Communication (IMC) dan Strategic Management of Teras Cikapundung's Brand Communication Programmes; 3) Model strategi komunikasi merek wisata kota buatan Teras Cikapundung yang menunjukkan urutan aktivitas kontruksi strategi yang dilakukan oleh pihak komunikator.
\end{abstract}

Kata kunci: Strategi komunikasi merek; Teras Cikapundung; wisata buatan.

\section{INTRODUCTION}

Man made tourism is an alternative place to tour the city, but also as an object of family education and entertainment. Many artificial tours in the city of Bandung can be seen in the green open areas that are used as parks. The attractiveness of city parks is a reason for residents to come and joint to the park in the weekend time. One of the city residents' choices is the Teras Cikapundung ( $\mathrm{TeCi}$ ) or also known as the Cikapundung Amphitheater on the riverbanks of the Cikapundung River. The Teras Cikapundungs was successfully created, one of which was by arranging the Cikapundung River became a popular tourist attraction as well as being a brand of Bandung (Saidah \& Rozalena, 2019).
Since revitalized in 2013, the Cikapundung River began to show an attractive and positive impression (Saidah \& Rozalena, 2019). The fruit of the river revitalization is equipped with public facilities and the surrounding park. Revitalizations of the Cikapundung riverbanks and borders basically aims to save the country's assets, restore the function of river, especially in areas that are flooded from upstream to downstream. The city of Bandung with its creativity made artificial tours from this revitalization process. In terms of the current characteristics of the people who tend to like outdoor activities and take pictures to be posted on their social media. Based on this, the revitalization of the Cikapundung River into a man made tourism is actually very appropriate to be built especially in attracting local, national and even 
international tourists to visit even though the purpose is not just tourism but also related to education and others (Yuliana, 2019). In addition, automatically in accordance with the 2014-2018 Mayor of Bandung program, this revitalization is aimed at increasing the achievement of the citizens' happiness index.

The existence of Teras Cikapundung tourism has provided a new treasure for the Babakan Siliwangi area, especially in the fields of education, religion, environment, agriculture, fisheries and forestry. The great potential of the Cikapundung River revitalization has also succeeded in creating a creative activity area. This also proves that creativity has emerged as part of the City of Bandung as the CCN (Creative Cities Network) or the world's creative city. Based on the brand and potential created from the Cikapundung River, it shows that Bandung City has an identity in the form of a city name, logo, image and symbols or icons that are attached.

In its development, the addition of man made tourism is interconnected with the vision of Dignified Bandung as stipulated in the Bandung City Regulation Undang-undang Nomor 09 Tahun 2009 concerning the Bandung City's RPJMD in 2009-2013. The vision of the City of Bandung is "Strengthening the City of Bandung as a City of Dignified Services". Dignified city is defined as a city that has identity, self-respect and pride for all its citizens, has excellent public service without distinguishing status. The direction of the vision is to portray the city of Bandung as a service city. The city of Bandung as a center of growth in the service sector that provides benefits for residents of Bandung in particular, West Java and national in general. Dignified services city has five dimensions which contain (1) fulfillment of clean, healthy, beautiful, green and flowering living conditions; (2) meeting the conditions of a safe, orderly, stable and dynamic social environment; (3) fulfillment of economic environmental conditions, so that the economic prosperity of its citizens is achieved; (4) fulfillment of religious environment conditions that are full of tolerance, noble character and pluralistic life awareness; (5) fulfillment of balanced and harmonious spatial conditions.

Therefore, in the effort to achieve this vision, the motto "Fighting with Dignity" is also upheld, namely, clean, prosperous, obedient, friendly. In an effort to realize the Teras Cikapundung as a city tourist destination, several events are held almost every day. The support of residents around the riverbanks was apparent by holding a movement to care for the environment. Some communities are inseparable from keeping the river clean. Community care about the Cikapundung River began to emerge in the areas that were flowed by the river, the communities from various community groups worked together to clean up the garbage in the river.

The Teras Cikapundung, located in the Babakan Siliwangi (Baksil) urban forest area, is also a green area created by the Bandung City Government under the direction of Mayor Ridwan Kamil. Satgas Operasional Sumber Daya Air Balai Besar Wilayah Sungai (BBWS) Citarum, Yuliana said that the concept of the transformed riverbank to be urban in character without losing its ecological side. The purpose of this Teras Cikapundung was to provide open public space for the citizens of the City of Bandung and its surroundings. The builder's function is held as a place for socializing, chatting comfortably. The Teras Cikapundung was opened to the general public in December 2015, and the inauguration was carried out by the Minister of Public Works and the Bandung City Government in mid-2016 in full work by the Balai Besar Wilayah Sungai (BBWS) Citarum valued at IDR 3.2 billion rupiah (Yuliana, 2019).

For this reason, man made tourism such as the Teras Cikapundung requires managers' strategies to introduce and maintain potential tourists, roles, functions and added value of $\mathrm{TeCi}$ without having to forget the cleanliness of the river environment. The intended strategy is full support in the introduction and in particular communicating the identity and image of the Teras Cikapundung as a place that builds solidarity and friendship between city residents and tourists in general. Therefore, in the preparation of strategy it needs to be supported by the diversity of natural wealth, culture, and man-made products that are targeted or visited by tourists. There is no exception to the strategy in terms of communicating the Teras Cikapundung brand as the main environmental tourism destination in the city of Bandung nowadays. One strategy that is carried out is to manage brand communication strategically through public approaches, the media and its results at any time. That is, to manage brand communications, organizations or companies still refer to the planning of integrated marketing communication programs (IMC) that were developed previously.In this regard, this research further explores how the brand communication process is built, the strategies undertaken in building the Teras Cikapundung brand and the construction of models that can be used as communication patterns of the Teras Cikapundung brand communication strategy. 


\section{LITERATURE REVIEW}

\subsection{Brand Communication Concepts}

Brand communication is a concept of a more specific understanding of the implementation of marketing communication. For tourist sites, a name or brand is an identity, image and aspiration. Identity shows the reason why a city must have a slogan or brand that is very different from other cities and has different features, even in one tourist attraction. The brand image is identified with what the city represents. In this case brand awareness is the ability to identify categories. Potential city visitors can recognize and remember the city through the city's slogan or brand in detail (Andriyanto, 2018)

Marketing communication also describes the "voice" of a brand and as a tool that can be used to build dialogue and relationships with consumers. Likewise, in the context of actual communication, marketing communication is a channel for communicators to transfer messages to the recipient (audience), allowing for many unpredictable effects and unpredictable feedback about city brands (Andriyanto et al., 2018).

Kliatchko suggested three important elements such as the three pillars of the IMC, which are audience focused, channel focused, and results oriented. As a concept and idea, IMC requires a line of thought about holistic brand communication planning based on a strategic approach dealing with an audience (customer) oriented to action change. IMC also requires the implementation of promotional activities by consumer databases, customer information management, development and planning of messages delivered through communication channels (channels focused). Finally, evaluate and measure the synergy of brand communication programs (results driven) (Kliatchko, 2002).

Brand loyalty is the impression of a top brand in memory that is attached to strong customers and to change brand loyalty (Entaswara, 2008). Yuwo, Ford \& Purwanegora (2013) stated that brand loyalty is the core of brand equity; if customers feel a bond with the brand, they will demonstrate loyalty towards that brand (Yuwo, H., Ford, J. B., \& Purwanegara, 2013).

The concept of the importance of integrated is related to all elements of effective communication, IMC pillars, and environmental management in the con itself. Thus, marketers/management/government can manage communication appropriately. Integrated also called collaboration requires all elements of the marketer to support organizational goals, forming an open flow of information (Entaswara, 2008).

\subsection{Destinations Branding}

Destination branding is part of tourism brand communication as an effort to change the way a person perceives a place or destination. In destination branding also includes differences in one location with another location as a tourist destination. In fact, this destination branding can change the image of an area or region. Destination awareness or salience is at the foundation of the hierarchy (Almeyda-Ibáñez \& George, 2017). Citing the statements of Morgan and Pritchard (2004) which suggest five stages to carry out destination branding in an effort to change the image of an area, namely

1. Market investigation, analysis and strategic recommendations: the initial stage of forming a city branding, regional marketers doing research and mapping of market potential, everything that can be developed, and the formulation of strategies);

2. Brand identity development: the brand identity stage is formed based on the vision, mission and image that the region wants to form);

3. Brand launch and introduction: communicating the vision, in this case after the tagline was introduced, then the existing brand was introduced by involving all existing components through media relations, such as advertising, direct marketing, personal selling, websites, brochures, or event organizers, film markers, destination marketing organizations (DMOs) and journalists);

4. Brand implementation: includes the process of elaborating a budget compilation to support various marketing communication programs in delivering brand messages; budgeting is an important aspect in doing a branding;

5. Monitoring, evaluation, and review: monitoring is carried out on the program being implemented to detect irregularities, deficiencies, and so on; the results are evaluated for improvement (Adona, Nita, \& Mafrudoh, 2017).

In addition, to realize brand communication that has an impact, it is necessary to plan and manage natural, socio-cultural attractions and special interest attracttions must be based on national and regional development plan policies. This is very important in connection with planning the development of tourist attractions that must be able to assume policy plans that are appropriate to the area concerned. Therefore, a tourist attraction should meet the requirements for regional development. Maryani (1991) states these 
requirements, including (1) What to see, in that place there must be tourist objects and attractions that are different from those of other regions. In other words the area must have special attractions and cultural attractions that can be used as "entertainment" for tourists. What to see includes natural scenery, activities, arts and tourist attractions, (2) What to do, in addition to the many things that can be seen and witnessed, recreational facilities that can make tourists feel at home staying long in that place, (3) What to buy, tourist destination facilities must be available for shopping facilities, especially souvenirs and folk crafts as souvenirs to be brought back to their place of origin, (4) What to arrive, including accessibility when visiting the tourist attraction, what vehicles will be used and how long it will take to arrive at the destination, and (5) What to stay, how the tourist stay for a while on vacation (Kirom, Sudarmiatin, \& Putra, 2016).

\section{RESEARCH METHOD}

The location of this Teras Cikapundung tourism study is on the banks and borders of the Cikapundung River, Bandung City. The informants in this study were the parties from the Dinas Pengelolaan Sumber Daya Air (PSDA) West Java, Satgas Operasional Sumber Data Air Balai Besar Wilayah Sungai (BBWS), the Culture and Tourism Office, the Public Works Office and the Bandung City Environment Agency (BPLH), the sub-district, the Cikapundung care community, residents around the Cikapundung River and visitors (tourists) along the Cikapundung River bank. revitalized.

Sources of data in this study consisted of key informants, places and events as well as Teras Cikapundung's documents/archives. In qualitative research the informant is an important factor in data retrieval. Data collection techniques were carried out through in-depth interviews, Focus Group Discussion (FGD), observation and analysis of documents obtained from various sources, both primary and secondary. In this research, Miles and Huberman's interactive analysis model is used, namely data collection, data reduction, data presentation, and drawing conclusions.

Researchers conduct pre-test research through Focus Group Discussion (FGD) with several questions related to responses, hopes, activities, excellent tours and community relations with the city government. FGD is also called group interview which is classified as a type of focused or structured interview. The FGD was chosen in order to reveal the group's perception of a problem in this case several Cikapundung River activist communities through discussion and question and answer activities.

\section{RESULT AND DISCUSSION}

\subsection{Teras Cikapundung Overview}

Based on observation and literature from Dinas Pengelolaan Sumber Daya Air (PSDA) West Java and Badan Pengelolaan Lingkungan Hidup (BPLH) Bandung, the Cikapundung River has a length of 28 kilometers and crosses 7 subdistricts namely, Cilengkrang, Cidadap, Coblong, Bandung Wetan, Cicendo, Bandung Well, Regol and Lengkong, and Kidul Bandung districts.

The revitalization of the Cikapundung river in Coblong Subdistrict and especially close to the Babakan Siliwangi area made the creative idea of opening a new tourism area made environmentally oriented. The construction of the Teras Cikapundung results from periodic mapping of the current situation as soon as the idea is rolled out by the city government through the Balai Besar Wilayah Sungai Citarum (BBWS) (Yuliana, 2019).

Babakan Siliwangi, located in the middle of the Cikapundung River, has residents with a stronger sense of solidarity and mutual cooperation. In addition, this kelurahan has a large number of residents living on the banks of the Cikapundung River. Geographically, Lebak Siliwangi Village has a large flat / choppy area (Halimatusadiah, Dharmawan, \& Mardiana, 2012).

An integrated man made tourism is a concept was chosen that could make visitors comfortable when they came and gathered here. BBWS Citarum finally improved and empowered it along the Cikapundung River basin. Among them by relocating a number of illegal buildings on the border and river banks, cleaning the river water from household waste and the like, removing mud deposits, and providing tourist transportation services in the form of rubber boats. The construction of all the main tourist facilities will still improve environmental management (Amdal) with 15 infiltration wells.

\subsection{The Process of Forming Brand Communi- cation}

The revitalization of the Cikapundung is motivated by the image of the Cikapundung river which has received the title of the dirtiest river in the world on the Citarum river (Yuliana, 2019). Several community care (Cika-Cika and Komunitas Sungai Clkapun- 
dung) said that the problem of the Cikapundung River is no less complicated, the river water discharge is increasingly shallow with an abundance of rubbish and waste as well as river banks that are converted into garbage dumps and illegal buildings. Along with the government program, revitalization was carried out and the Teras Cikapundung became a tourist attraction made in Bandung.

The of researchers analysis from collective data dan observation nonparticipate show that Teras Cikapundung has now metamorphosed into one of the tourist icons made in the city of Bandung which is a tourist destination for local and national tourists. For this reason, brand communication regarding Teras Cikapundung tourism is important to be communicated on an ongoing basis. Successful brand communication will make the brand into a characterization, which is getting recognition related to the image displayed.

\subsection{Message Model Analysis}

In explaining the process of forming a communication brand tourism made by Teras Cikapundung in a theoretical perspective, this study uses a Message Model from Pamela Angell (Angell, 2007).

Researcher found that the process of forming a tourism brand communication made by Teras Cikapundung consists of several stages.

1. Determine the target audience

Based on Bandung Tourism Office, tourist visits to the city of Bandung after the construction and revitalization of man made tourism, experienced an increase. The indicator of this increase is based on tourist arrivals through the train station and airport. In the process of developing brand communication, determining the target audience is the most critical step. The identification of the target audience, the source of the message (communicator) can easily communicate the product, namely the existence of tours made by the Teras Cikapundung.

2. Select Media

The media used to communicate the tour brand made by Teras Cikapundung are carried out routinely both online and offline. Offline brand communication media that is directly through face to face or through mass media, one of which is radio. Communication via radio is on talk shows.

Online brand communication media through Twitter, Facebook, and website. The use of the media Twiter with the link of the Bandung Culture and Tourism Office @Disparbud_bdg began to be active in September 2013 with a followers of up to 14700 followers. Facebook used has a link with the Bandung City Culture and Tourism Office. Instagram Disparbud.bdg to date has been followed by 12900 followers. The Culture and Tourism Office website displays the most complete information compared to other social media that are used, because it is in the DISPARBUD link. This Bandung.go.id explained the annual DISPARBUD calendar of Bandung City.

3. Design the contents of the message

Fill in the message on the Twiter that presents various events both before, during or after the event is carried out. In Facebook the message displayed is Disparbud address and other identities such as Instragram name, operational time and others. Information on Facebook is more complete than Twiters and Instagram, namely by displaying tourist attractions as well as about the history or origin of the history of art, culture and places in the city of Bandung. The information contained on Instagram is almost the same as that found on Facebook, supplemented by documentation of other Bandung city tourism activities.

4. Determine the source of the message

Communicators in communicating the tourism brand made by the Teras Cikapundung are specifically carried out by the relevant parties, namely the City of Bandung Tourism and Culture Office and the Citarum River Basin Agency (BBWS).

The Department of Tourism and Culture of Bandung City communicates the Teras Cikapundung in relation to the work program, which is to introduce and publish tourist destinations in the city of Bandung. BBWS Citarum communicates as well as the person in charge of the Teras Cikapundung destination related to the project in revitalizing the Cikapundung River, which so far has a negative image. In this case the BWWS Citarum is well aware of the advantages and problems of this Teras Cikapundung tour, so it can be said that the BWWS is a credible community specifically for Teras Cikapundung tours.

5. Overcoming interference

The existence of Teras Cikapundung-made tourism which is not specifically communicated makes the Teras Cikapundung an iconic city of Bandung. However, if seen from the history before and after the revitalization of the Cikapundung river, the Teras Cikapundung is an extraordinary thing. Slums, illegal settlements and landfills become an iconic and fun tourist destination to visit. 
6. Convey the message

Marketing communication activities are circular in nature which include sending messages, communicating processes and responding to feedback speed. In sending communication messages must pay attention to the right momentum, anticipation of disruption, self-presentation, speed of evaluation and decision. Repetition of the communication process is caused by the stages of the communication process that must be passed in accordance with the conditions of consumers encountered in the field.

\subsection{Destination Branding Strategy}

Based on data collection, in defth interview, observation and data analysis through interactive techniques shows several results about destination awareness or salience is at the foundation of the hierarchy. This dimension is investigated under the topic of destination selection or the travel decision process (Konecnik, 2010). Pike \& Page stated that awareness represents the strength of the brand presence in the mind of the target market (Pike, S., \& Page, 2014). The government through the City of Bandung Tourism and Culture Office with the Citarum River Basin Agency (BBWS) and related institutions should introduce the Teras Cikapundung as a city tourism destination. Some destination branding strategies that will be carried out will be explained below.

1. Restoration and revitalization of the Cikapundung River

This restoration was carried out as a consistent step in structuring along the borderline of the Cikapundung River especially to accommodate the social activities of the community and explore the potential around it.

With the restoration of the Cikapundung River, it is hoped that the availability of facilities and infrastructure that is accommodative and representative both in terms of function and aesthetics, to support the Clean Cikapundung program. In addition, the Cikapundung River Restoration program includes programs to maintain water quality, control floods, organize river banks and improve river bank functions that have a social function as a means for communities to interact with one another.

As a follow-up from the government in maintaining environmental harmony, the maintenance of $\mathrm{TeCI}$ along with the Cikapundung River Restoration activity involved the Cikapundung
Community and the support of BBWS Citarum working together to form 52 working groups. Based on this, the $\mathrm{TeCi}$ name or brand is not owned by one party, but rather involves all elements of citizens, governments, communities and media to make the river more beautiful and manicic while maintaining environmental awareness through reforestation, waste management, sedimentation management, reduction of household waste, including raising awareness and changing people's behavior.

2. Strengthening of element $3 \mathrm{~A}$

Element 3A covers cities with attractions, accessibility and amenities owned by the City of Bandung. The first Element A, attraction shows the fulfillment of the element of tourism potential made by the city river, which is the result of revitalization, not only for tourism activities in general, but as a means of education, sports, religion and others.

The second element $\mathrm{A}$, which is accessibility that shows the Teras Cikapundung is an easily accessible area and provides an alternative for environmental tourism.

The third element, namely amenity, which means the Teras Cikapundung provides facilities to complement visiting tourists, such as information media, parks, monuments, gazebos, ponds, parks, and bridges (Saidah \& Rozalena, 2019).

\section{DISCUSSION}

\subsection{Teras Cikapundung Brand Communication Strategy}

The revitalization of the park and the Cikapundung River in the Babakan Siliwangi region, which became known as the Teras Cikapundung, were included in the national strategy, but in the process involved various parties and related agencies. Collaboration of various parties related to the work of the banks of the riverbanks and border areas of the Babakan Siliwangi region, resulted in an iconic artificial tour of Bandung. The enthusiasm of the citizens in the existence of the park was very large as seen from the tour (Rozalena, 2019).

Researcher stated that river tourism is not only limited to being a tourist destination but for other activities such as education and even for commercial advertising. Based on this, maintenance is a joint task so that this iconic park will remain the pride and brand of the city of Bandung, as a city famous for its artificial tours. In maintaining and strengthening the 
Teras Cikapundung tourism brand, a communication strategy needs to be carried out.

Furthermore, brand communication strategy is a strategy in communicating the brand, where the formulation process only begins after the process of forming a brand identity has occurred. The brand is not just a big name, in this case "Man made tourism Teras Cikapundung", but a way of life in which there are desires, promises and commitments that must be fulfilled. The desire and commitment in the restoration and revitalization of the Teras Cikapundung in addition to being a means to make Bandung citizens happy is also related to three aspects.

\section{Location of field trip}

Based on interviews with the community, community, district officials, it can be concluded that a very strategic location provides easy access to reach tourist attractions made by the Teras Cikapundung either by public or private transportation. In addition, the Teras Cikapundung is equipped with several supporting facilities as an attraction.

a. Amphitheater Teras Cikapundung. The main facilities of this Teras Cikapundung are stairs where visitors can do a lot of entertainment activities, such as entertainment shows such as live music, watching together football match events, exhibition activities, exhibitions and others.

b. Red bridge Cikapundung riverspot. This bridge is the identity or characteristic of the beautiful Teras Cikapundung in red connecting the banks of the Cikapundung River.

c. Teras Cikapundung Fountain. The fountain becomes the main attraction when the night falls in an eccentric style with colorful lights.

2. Community Awareness

Man made tourism by the Teras Cikapundung has been managed by the Cikapundung River community under the supervision of BWWS Citarum. Another activity carried out by BWWS Citarum and the Cikapundung River community is the socialization of the Cikapundung River to residents. The socialization was carried out massively in a subtle and indirect way, by making facilities for children to do activities such as playing soccer as well as swimming in the river by providing tire facilities. The activity around the river is expected to be able to make the community around the river not to dispose of up to the river, because the river is the activity of their children. Community awareness and concern for river cleanliness is a core objective of the activities of the socialization carried out by the BWWS Citarum and the Cikapundung River Community.

3. Environmental Hygiene.

Teras Cikapundung was created because of environmental problems such as low awareness and concern of the community towards rivers, forests that are often touched by irresponsible hands and other environmental problems. Man made tourism and the Cikapundung Teras river have a great impact not only on the economy, social but also the environment. The role of various parties, both the River Basin Center (BBWS), the Bandung City Government Service, as well as the community of environmental activists who often carry out activities around the river, made public awareness around the river begin to be educated with the existence of the Teras Cikapundung.

\subsection{Developing Brand Communication Programs}

Researchers get the results of construction of several destination branding strategies following the brand communication program developed by the manager of Teras Cikapundung.

1. Pictorially Recognized

Cikapundung terrace is a park with supporting facilities for selfies. In addition, the beautiful and interesting impression was also disseminated by the Department of Tourism and Culture of the City of Bandung, BBWS Citarum and the Department of Public Works itself. This photo moment is the basic capital for the distribution of unique images from the Cikapundung Terrace to across the region.

2. Quantity / strength of positive qualities

This program includes the power to link the city of all identities, uniqueness and icons of the Teras Cikapundung through facilities that can influence visitors. The Cikapundung Terrace is now synonymous with water tourism, education, sports and entertainment with the strength of the collaborative community of art, fashion, music, architecture, design, and information technology.

3. Conversational value

The development of this program emphasizes attractive facilities by creating an image of every attraction and service provided by the city. The Cikapundung terrace is more easily known by word of mouth with the statement "a new and cool hangout", "botram weh di TeCi!", "main kukuyaan di TeCi" and so on. The existence of views about river revitalization, can influence visitors to 
redistribute this information to family, friends, or business partners.

3. Media recognition

Provision of media and information channels that allow visitors to come from various transportation networks. In addition to easy access to informative news throughout the world, information on Teras Cikapundung is supported by the provision of an attractive and selling tourism office online media, for business and tourism information. Provision of online media for all planned routine activities. The government is committed to holding various events, nationally and internationally, so that $\mathrm{TeCi}$ is increasingly useful.

\subsection{Brand Communication Strategy Model}

The model of brand communication strategy is constructed by considering a series of activities in the formation of a tourist communication brand made by the Cikapundung Terrace which includes audience identification, communication media selection, determining the message content, determining the source of the message, overcoming interference and sending messages. Likewise the Teras Cikapundung strategy includes aspects of the location of field trips, community awareness and environmental cleanliness simultaneously supporting the communication strategy of the Teras Cikapundung tourism brand.

The three pillars of the attributes of integrated marketing communication (IMC), which have been planned are aligned with the city government in the management strategy for the Teras Cikapundung communication program. Bandung, a prosperous city for its inhabitants, can be seen through increased participation and cooperation from all walks of life. In this case, the idea of the Bandung mayor in his vision must be implemented quickly by the Bandung Tourism Promotion Board (BP2KB) through a management strategy to manage communication for the brand.

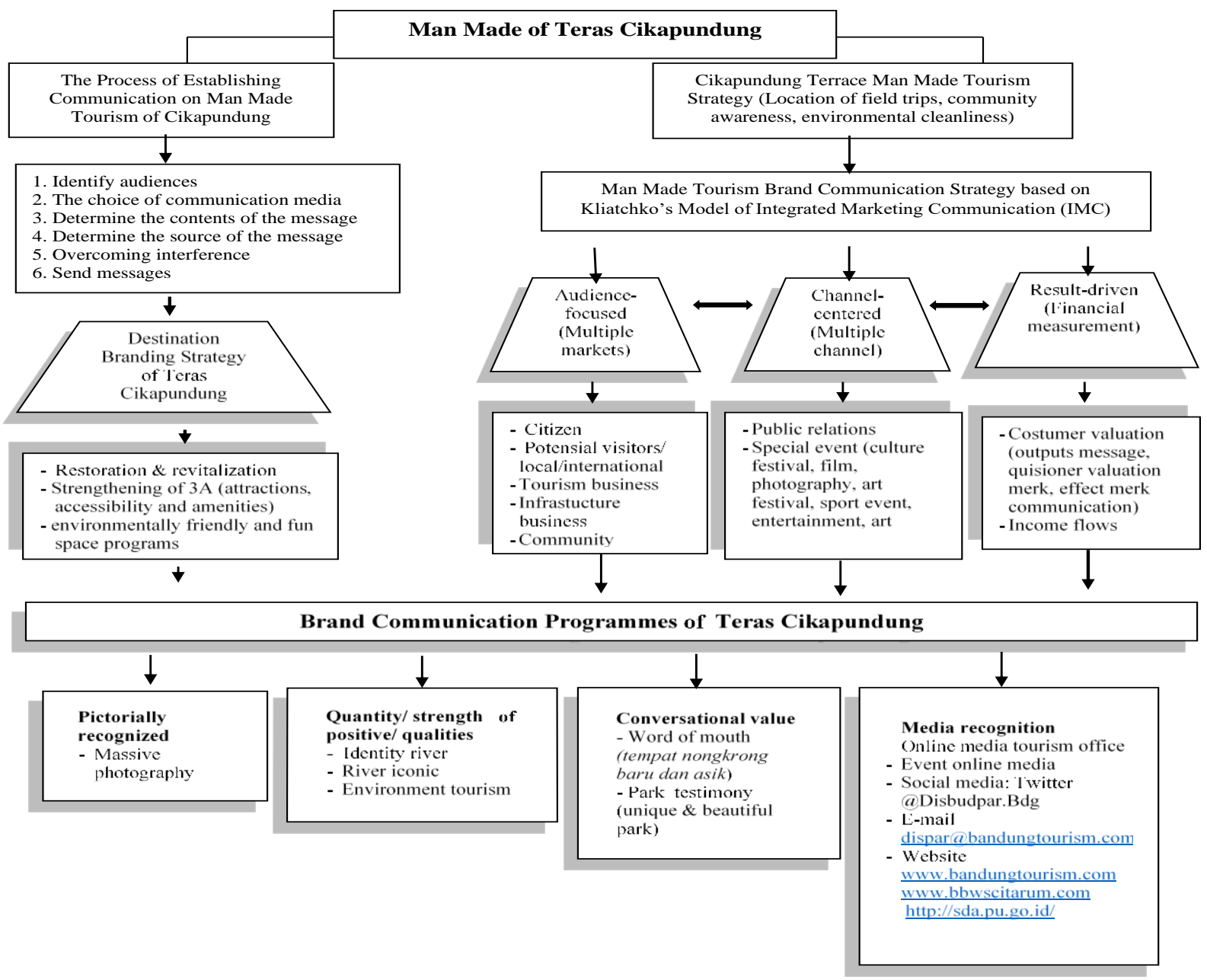

Source: IMC, Jerry Kliatchko (2005) and writer construction (2019)

Picture 1. Integrated Brand Communication of Teras Cikapundung's Model 


\section{CONCLUSION}

Based on the previous presentation, the following conclusions can be conveyed.

1. The process of forming brand communication begins with the idea and the idea of restoration and revitalization of the Cikapundung River by related parties, including supporting the vision of the City of Bandung BERMARTABAT. The process is carried out by applying the MESSAGE Model, which identifies the audience, chooses the communication media, determines the contents of the message, determines the source of the message, overcomes interruptions and sends messages. Next, develop a destination branding strategy.

2. The strategy in communicating the name / identity of the tour made by Teras Cikapundung related to three aspects; the location of field trips, community awareness and environmental cleanliness supported by the process of forming effective brand communication will make the tour brand made by the Cikapundung Teras strong. A strong brand is basically one that has a strong position, which is distinctive or has its own character supported by the application of the three pillars of Integrated Marketing Communication (IMC) in the form of audience focused, channel centered, and result driven. Furthermore, the preparation of its brand communication program through pictorially recognized, quantity / strength of positive / qualities, conversational values and media recognition.

3. As for constructing the model of communication strategies for the tourism brand made by the Cikapundung Terrace, it is explained as follows. First, build the process flow forming names or identities. Second, it illustrates the application of the Kliatchko Integrated Marketing Communication Model. These two pathways will form a brand communication strategy model that can be applied to similar types of rivers to the Cikapundung River.

\section{ACKNOWLEDGEMENT}

This scientific work is the result of research funded by the Directorate of Research and Community Service of the Ministry of Research Technology and Higher Education through the Penelitian Dosen Pemula (PDP) grant program for the 2019 fiscal year.

\section{REFERENCES}

Adona, F., Nita, S., \& Mafrudoh, L. (2017). City Branding: Strategi Pemasaran Pariwisata Kota Padang. Seminar Nasional Multi Disiplin Ilmu
\& Calll For Papers UNISBANK KE-3 (SENDI_U 3, 536-546. Retrieved from https://adoc.tips/city-branding-strategipemasaran-pariwisata-kota-padang.html

Almeyda-Ibáñez, M., \& George, B. P. (2017). Place Branding in Tourism: A Review of Theoretical Approaches and Management Practices. Tourism \& Management Studies, 13(4), 10-19. https://doi.org/10.18089/tms.2017.13402

Andriyanto, Evan, N., Budiono, H., \& Wiyanto, H. (2018). Pengaruh Brand Image dan Corporate Branding Terhadap Keputusan Pembelian Konsumen Smartphone Samsung Melalui Brand Equity Sebagai Mediasi Pada Mahasiswa/i S1 Manamajen Fakultas Ekonomi Universitas Tarumanegara. 2510262. Retrieved from http://cmbs.untar.ac.id/images/prosiding/2018/0 40_CMBS2018_Njo-Herlina-Hendra.pdf

Angell, P. (2007). Business communication design: creativity, strategies, and solutions (2nd ed.). Boston: McGraw-Hill.

Entaswara. (2008). Think IMC. Efektivitas Komunitas Untuk Menciptakan Loyalitas Merek dan Laba Perusahaan. Jakarta: Gramedia Pustaka Utama.

Halimatusadiah, S., Dharmawan, A. H., \& Mardiana, R. (2012). Efectivity of Participatory Institution in Citarum River Upstream Watershed. Jurnal Sosiologi Pedesaan, 6(1), 1-20.

Kirom, N. R., Sudarmiatin, \& Putra, I. W. J. A. (2016). Faktor-faktor Penentu Daya Tarik Wisata Kepuasna Wisatawan. Jurnal Pendidikan: Teori, Penelitian, Dan Pengembangan, 1(3), 536-546.

Kliatchko, J. (2002). Understanding Integrated Marketing Communication. Pasig City, Philippines: Inkwell Publishing.

Konecnik, M. (2010). Extending the tourism destination image concept into customer- based brand equity for a tourism destination. Ekonomska Istrazivanja, 23(3), 24-42.

Nugraha, A. (2019). Teks Wawancara. Bandung: Bagian Program Data Informasi Dinas Pariwisata dan Kebudayaan Kota Bandung.

Pike, S., \& Page, S. J. (2014). Destination Marketing Organizations and Destination. Tourism Management, 41, 202-227.

Rozalena, A. (2019). City Branding Models Based On Artificial Tourism. In D. Dina (Ed.), ISBN 2715-2030 (pp. 166-172). Retrieved from https//www.icmimuda.org

Saidah, I., \& Rozalena, A. (2019). Model City Branding Melalui Revitalisasi Sungai Cikapundung. 
MediaTor, 12(2). https://doi.org/https://doi.org/ 10.29313/mediator.v12i2.5026

Yuliana, A. Y. (2019). Teks Wawancara. Bandung: Satuan Kerja Operasi dan Pemeliharaan Sumber Daya Air Balai Besar Wilayah Sungai (BBWS) Citarum.
Yuwo, H., Ford, J. B., \& Purwanegara, M. S. (2013). Customer-Based Brand Equity for a Tourism Destination (CBBETD): The specific case of Bandung City, Indonesia. Organizations and markets in Emerging Economies. Organizations and Markets in Emerging Economies, 4(1), 8-22. 